\title{
Unusual presentation of osteomyelitis: A clinical dilemma
}

\author{
*Vindika Prasad Sinhabahu1, Sarah Jamison²
}

Sri Lanka Journal of Child Health, 2020; 49(4): 399-400

DOI: http://dx.doi.org/10.4038/sljch.v49i4.9276

(Key words: Osteomyelitis, unusual presentation, child)

\section{Introduction}

Osteomyelitis is a bacterial infection of the bone ${ }^{1}$. In paediatric osteomyelitis, commonest mechanism is haematogenous inoculation of the bone during an episode of bacteraemia. Osteomyelitis can result from penetrative trauma or spread from a contiguous site of infection ${ }^{1}$.

\section{Case report}

A five year old New Zealand European boy was referred for further evaluation to the Children's Emergency Department (CED), Starship Children's Health following an abnormal radiograph of the right femur (Figure 1).

He had a history of intermittent right thigh pain and limp for 4 weeks which resolved 2 weeks ago. There was no history of trauma or fever. General Practitioner had seen the child and arranged an Xray of right femur and hip joint. X-ray showed a periosteal reaction in the proximal femoral shaft without any evidence of fracture (arrow in Figure 1).

On presentation to $\mathrm{CED}$, his temperature was $36.5^{\circ} \mathrm{C}$. His pulse rate was $80 / \mathrm{min}$, respiratory rate $24 /$ min and oxygen saturation $97 \%$ on air. His gait was normal. His lower limbs were not tender and all joint movements were normal. The rest of the physical examination was unremarkable. The differential diagnoses were undisplaced fracture of femur, osteomyelitis and malignancies such as bone tumours and leukaemia.

Full blood count showed a haemoglobin level of 126 $\mathrm{g} / \mathrm{L}$, white cell count $8.78 \times 10^{9} / \mathrm{L}$ with neutrophils $2.88 \times 10^{9} / \mathrm{L}$ and lymphocytes $4.76 \times 10^{9} / \mathrm{L}$, platelet count $277 \times 10^{9} /$ L. C-reactive protein (CRP) was

\section{${ }^{1}$ Fellow, ${ }^{2}$ Service Clinical Director, Children's Emergency Department, Starship Children's Health, Auckland, New Zealand \\ *Correspondence: sinbad.lk@gmail.com \\ iD) \\ orcid.org/ 0000-0003-0065-2845}

(Received on 23 April 2019: Accepted after revision on 24 June 2019)

The authors declare that there are no conflicts of interest

Personal funding was used for the project.

Open Access Article published under the Creative

Commons Attribution CC-BY

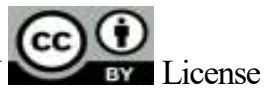

$<0.6 \mathrm{mg} / \mathrm{L}$ and erythrocyte sedimentation rate (ESR) was $6 \mathrm{~mm} / 1^{\text {st }}$ hour. Serum electrolytes, calcium, phosphate, albumin and liver function tests were normal. Lactate dehydrogenase was $276 \mathrm{U} / \mathrm{L}$ which was elevated (Reference range: $120-250 \mathrm{U} / \mathrm{L}$ ). In the background of the normal physical examination and unremarkable full blood count and inflammatory markers, it was decided to perform a magnetic resonance skeletal survey. It showed nonspecific intramedullary signal abnormality with contract enhancement and smooth periosteal new bone formation in proximal right femoral diaphysis.

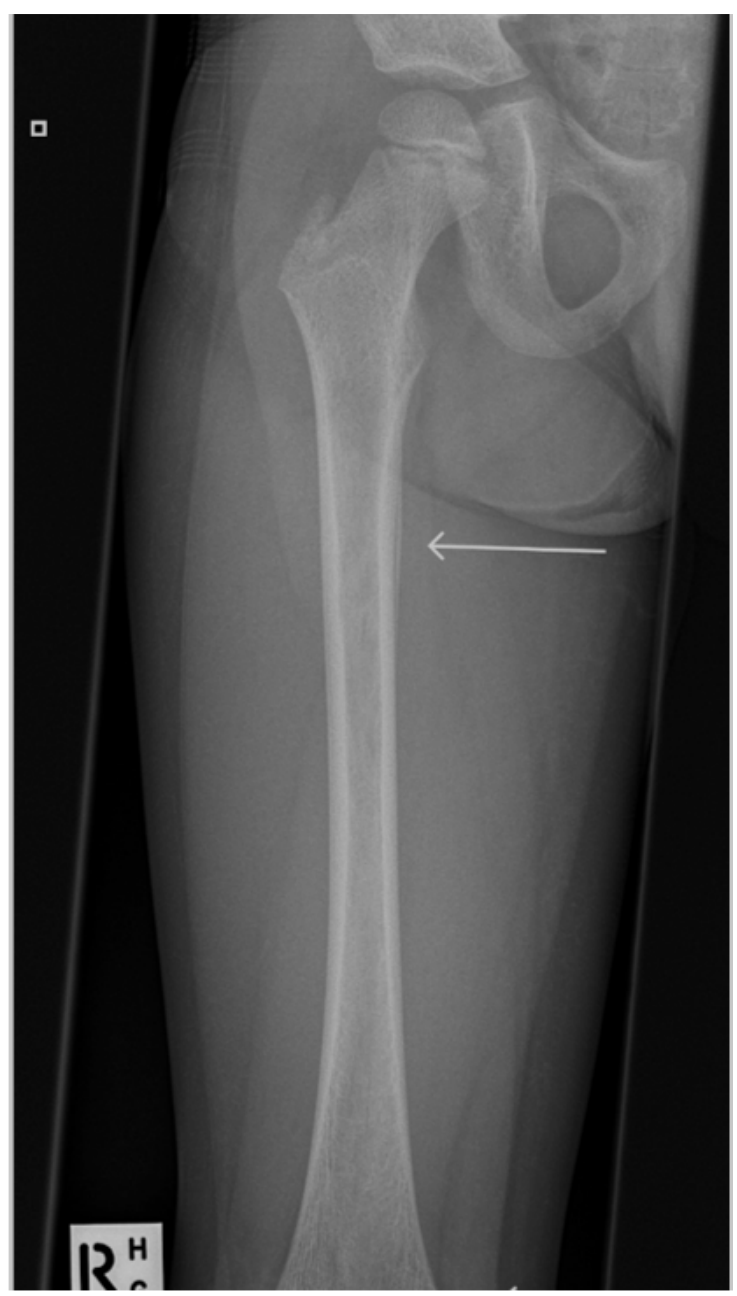

Figure 1: X-ray of right femur showing periosteal reaction

Bone biopsy was carried out from the right proximal femur. Gelatinous material was noted in the medullary cavity. Histology showed evidence of chronic osteomyelitis. Peripheral blood culture, tissue culture and bone marrow culture from the 
proximal femur did not yield any growth. As the cultures were negative, it was decided to observe the child without antibiotics. He had an undisplaced pathological fracture of the proximal right femur 2 days following the bone biopsy. He was placed on a cast. Repeat radiograph in 2 weeks showed callus formation. Child was asymptomatic when reviewed 3 months later.

\section{Discussion}

A study in New Zealand estimated the incidence of osteomyelitis in New Zealand European children to be 111 per million and Maori and Polynesian children to be 428 per million ${ }^{2}$. Osteomyelitis is classified according to the duration between diagnosis and onset of symptoms into three groups: acute (up to 2 weeks), subacute ( 2 weeks to 3 months) and chronic ( $>3$ months $)^{3}$. Our patient falls into the subacute category.

Sensitivity of ESR and CRP in bacterial osteoarticular infection on admission was $94 \%$ and $95 \%$ respectively and combination of ESR and CRP gave a sensitivity of $98 \%{ }^{4}$. Radiographs have low specificity and sensitivity for osteomyelitis ${ }^{3}$. Magnetic resonance imaging (MRI) has high sensitivity $(82 \%-100 \%)$, and specificity $(75 \%-$ $99 \%$ ) in diagnosis of osteomyelitis ${ }^{3}$. MRI, ESR and CRP were not helpful in diagnosis of osteomyelitis in our patient. Bone biopsy was carried out as history and initial investigations did not lead to a diagnosis.

There were dilemmas about diagnosis and management in our patient. The dilemma about the initial diagnosis resolved with the bone biopsy. Resolved symptoms, normal inflammatory markers, nonspecific MRI and no growth in cultures favoured observation rather than antibiotics in our patient.

\section{Acknowledgement}

We thank the Departments of Radiology, Pathology and Orhopaedics in Starship Children's Health for their contribution in managing this patient.

\section{References}

1. Zaoutis $\mathrm{T}$, Localio AR, Leckerman $\mathrm{K}$, Saddlemire S, Bertoch D, Keren R. Prolonged intravenous therapy versus early transition to oral antimicrobial therapy for acute osteomyelitis in children. Pediatrics 2009; 123(2): 636-42.

https://doi.org/10.1542/peds.2008-0596

PMid: 19171632 PMCid: PMC3774269

2. Rossaak M, Pitto RP. Osteomyelitis in Polynesian children. International Orthopaedics 2004; 29(1): 55-8. https://doi.org/10.1007/s00264-004-05973

PMid: 15490163 PMCid: PMC3456946

3. Chiappini E, Mastrangelo G, Lazzeri SA. Case of acute osteomyelitis: An update on diagnosis and treatment. International Journal of Environmental Research and Public Health 2016; 13(6): 539.

https://doi.org/10.3390/ijerph13060539

PMid: 27240392 PMCid: PMC4923996

4. Pääkkönen $\mathrm{M}$, Kallio $\mathrm{MJ}$, Kallio $\mathrm{PE}$, Peltola H. Sensitivity of erythrocyte sedimentation rate and $\mathrm{C}$-reactive protein in childhood bone and joint infections. Clinical Orthopaedics and Related Research. 2009; 468(3):861-6. https://doi.org/10.1007/s11999-009-09361

PMid: 19533263 PMCid: PMC2816763 